\title{
Effect of Supply of Metabolizable Protein on Whole Body and Splanchnic Leucine Metabolism in Lactating Dairy Cows
}

\author{
H. Lapierre*, J. P. Blouin, $\dagger^{, 1}$ J. F. Bernier,† C. K. Reynolds, $¥$ P. Dubreuil§ and G. E. Lobley\| \\ *Dairy and Swine Research and Development Centre, Agriculture and Agri-Food Canada, Lennoxville, Qc, Canada J1M 1 Z3 \\ †Département des sciences animales, Université Laval, Ste-Foy, Qc, Canada G1K 7P4 \\ ¥Department of Agriculture, The University of Reading, Reading, UK RG6 6AT \\ §Faculté de médecine vétérinaire, Université de Montréal, St-Hyacinthe, Qc, Canada J2S 7C6 \\ ||Rowett Research Institute, Bucksburn, Aberdeen, UK AB21 9SB
}

\begin{abstract}
The effect of the supply of metabolizable protein (MP) on protein metabolism across the splanchnic tissues was determined in six catheterized lactating Holstein cows. In a crossover design, two isonitrogenous (16.3\% $\mathrm{CP}$ ) diets balanced to provide a low (Lo-MP) or high (Hi-MP) supply of MP were fed over 35-d periods. After $24 \mathrm{~d}$ of feeding, $\mathrm{N}$ balance was determined over a 6 - $\mathrm{d}$ period. On d $33,\left[{ }^{13} \mathrm{C}\right]$ sodium bicarbonate was infused into one jugular vein for $6 \mathrm{~h}$, and hourly breath samples were collected. On d 34 or $35, \mathrm{~L}\left[1-{ }^{13} \mathrm{C}\right]$ leucine was infused into one jugular vein, and between 2 to $6 \mathrm{~h}$ of infusion, breath and blood samples were taken hourly from the portal and hepatic veins and an artery. Isotopic enrichments of plasma leucine, 4-methyl-2-oxopentanoate, and expired $\mathrm{CO}_{2}$ were determined for calculation of leucine kinetics. Net leucine absorption was greater, either on a direct basis (leucine transfer only) or corrected for portal-drained viscera metabolism to 4methyl-2-oxopentanoate and $\mathrm{CO}_{2}$ for the Hi-MP diet. There were no effects of diet on hepatic net flux of leucine across the liver, and, thus, more leucine was available to peripheral tissues with the Hi-MP diet. Combined with an increment in portal absorption of most of essential AA, this led to increased milk protein output, although it only represented $16 \%$ of the additional available leucine. Whole body leucine oxidation was also greater for the Hi-MP diet, as was leucine used for protein synthesis. Despite these changes, MP supply did not affect irreversible loss rate of leucine by portal-drained viscera and the liver; these averaged 35 and $20 \%$ of whole body irreversible loss rate, respectively. These ratios confirm the high metabolic activity of splanchnic tissues in lactating dairy cows, which are
\end{abstract}

Received December 7, 2001.

Accepted April 12, 2002.

Corresponding author: H. Lapierre; e-mail: lapierre@agr.gc.ca.

${ }^{1}$ Actual address: Shur-Gain, 5 Place du Commerce, suite 200, Brossard, QC, Canada, J4W 3E7. even greater than previously reported in growing ruminants.

(Key words: protein, splanchnic, metabolism, leucine)

Abbreviation key: BCAA = branched-chain AA, HiMP = high supply of metabolizable protein, $\mathbf{I E}=$ isotopic enrichment, ILR = irreversible loss rate, Lo-MP = low supply of metabolizable protein, $\mathbf{M P}=$ metabolizable protein, $\mathbf{M O P}=4$-methyl 2-oxopentanoate, $\mathbf{p A H}=$ para-aminohippurate, $\mathbf{P D V}=$ portal-drained viscera.

\section{INTRODUCTION}

Manipulation of either the quantity (MacRae et al., 1997a; Lapierre et al., 2000) or composition (Lobley et al.,1996; Blouin et al., 2002) of diets can alter the pattern and amount of absorbed AA in ruminants. These AA then undergo anabolic (protein synthesis) or catabolic (oxidation) fates, and the partition between these determines their efficiency of use for productive purposes. In both meat-producing and lactating ruminants, only limited quantitative information is available on the net use of individual AA and where in the body the anabolic and catabolic events occur. In growing cattle, for example, increases in diet quantity result in a stimulation of whole body protein turnover (Lobley et al., 1987; Lapierre et al., 1999a) that probably reflects increases in protein synthesis across some (Lobley et al., 1992), but not all (Lobley et al., 1994; Lapierre et al., 1999a), tissues. In contrast, in adult goats, the differences in whole body protein synthesis associated with stage of lactation appear to be dominated by metabolism of the mammary gland (Bequette et al., 1994). It is not known whether nutrition-induced changes in protein metabolism in lactating dairy cows are also mainly a response to metabolic events in the udder.

Although catabolism of several essential AA (histidine, methionine, and phenylalanine) occurs predominantly within the liver, others [lysine, threonine, and the branched-chain AA (BCAA)] are degraded predominantly at extra-hepatic sites (Pell et al., 1986; LeFloc'h et al., 1997; van Goudoever et al., 2000). In particular, 
oxidation of the BCAA can occur in a wide range of ruminant tissues (Goodwin et al., 1987), including both the digestive tract (Pell et al., 1986; Lobley et al., 1996; MacRae et al., 1997a) and mammary gland (Bequette et al., 1996 a, 1996b; Thivierge et al., 2002). The catabolism of BCAA by the digestive tract has two consequences. First, the amount of AA appearing in the mesenteric or portal vein will underestimate that absorbed from the small intestine (MacRae et al., 1997b; Berthiaume et al., 2001). Second, the amount of BCAA available for productive purposes may vary in response to changes in digestive tract metabolism. Thus, sheep with an intestinal parasite load oxidized more leucine in the digestive tract and had a lower net absorption than pair-fed controls (Yu et al., 2000), whereas flavomycin treatment increased net leucine absorption (MacRae et al., 1999). Raising intake of grass pellets from 800 to $1200 \mathrm{~g} / \mathrm{d}$ in sheep did not alter the fractional oxidation of leucine (MacRae et al., 1997a), but the absolute catabolism increased in proportion to elevated flux across the digestive tract. It is unclear, however, whether this was a response to the increased DMI and the resulting workload of the digestive tract, or to the elevated AA supply.

The current study examined the issues of partition of leucine between anabolic and catabolic fates in the dairy cow, when AA absorption is altered by metabolizable supply (MP), primarily accomplished by changes in protein degradability in the rumen. Attention was focused on the role of the splanchnic tissues and the proportion of the changes in whole body protein metabolism (based on leucine kinetics) related to milk output.

\section{MATERIALS AND METHODS}

\section{Animals and Treatments}

Six multiparous Holstein cows, averaging $597 \pm 39$ $\mathrm{kg}$ of BW and $210 \pm 7 \mathrm{DIM}$ at the beginning of the study, were housed in tie stalls in a heated barn (approximately $15^{\circ} \mathrm{C}$ ) lighted from 0600 to $2200 \mathrm{~h}$. Chronic indwelling catheters were surgically implanted as described by Huntington et al. (1989) at least 4 mo before the beginning of the experimentation. Briefly, Teflon catheters encased in silicone rubber tubing were implanted into one hepatic vein and in the portal vein, and Tygon catheters were inserted into two mesenteric veins and into the caudal aorta via a mesenteric artery. The right carotid artery was surgically raised to a subcutaneous position to provide access to arterial blood, should the permanent arterial catheter fail; this occurred in one cow. Cows were milked twice daily in a milk parlor at 0600 and $1800 \mathrm{~h}$. Milk production was recorded at each milking.
Table 1. Composition of two isoenergetic and isonitrogenous diets supplying high or low metabolizable protein (MP).

\begin{tabular}{lcc}
\hline \multirow{2}{*}{$\begin{array}{l}\text { Ingredients } \\
\text { g/kg DM) }\end{array}$} & \multicolumn{2}{c}{ Treatments } \\
\cline { 2 - 3 } & High MP & Low MP \\
\hline Corn silage & 338 & 330 \\
Grass hay & 229 & 225 \\
Corn & 240 & - \\
Soybean meal & 77 & - \\
Wheat distillers & 41 & - \\
Corn gluten meal & 5 & 40 \\
Rapeseed meal & 46 & 371 \\
Rolled wheat & - & 11 \\
Urea & - & 24 \\
Mineral \& vitamin premix & 25 & 1.62 \\
Estimation from NRC (2001) & 1.62 & 16.3 \\
NE, Mcal/kg DM & 16.3 & 1654 \\
CP, \% DM & 1930 & \\
MP, g/d &
\end{tabular}

${ }^{1}$ Calculated using the intake observed during the study with chemical composition of the feed ingredients reported in Table 2.

Two diets, balanced to be isonitrogenous $(16.3 \% \mathrm{CP})$ and isoenergetic (1.62 Mcal of $\mathrm{NE}_{\mathrm{I}} / \mathrm{kg}$ ), but differing in ruminal protein degradability, were tested within each cow according to a crossover design. One diet was estimated (NRC, 2001) to provide more MP (1930 g/d, HiMP), mainly through increased RUP, compared with the other (1654 g/d, Lo-MP). Composition of the diets is detailed in Table 1, whereas the chemical compositions of the feed ingredients are detailed in a companion paper (Blouin et al., 2002). Each experimental period lasted $35 \mathrm{~d}$. The diets were fed as a TMR in 12 equal meals per day, on even hours, to minimize postprandial variations. Cows had free access to water. Feed offered and orts were weighed daily. Quantities offered were fixed throughout the experiment and based on the average intake of the $2 \mathrm{wk}$ preceding the experiment in order to allow minimal refusals. The DM of corn silage was measured every week and TMR offered adjusted accordingly to ensure that the DM offered was constant throughout the study. One cow had a digestion problem with chopped hay in the TMR (stopped eating and became acidotic) and received the hay in two daily meals with the remaining ingredients fed as TMR at the same schedule as the other cows. The experimental protocol was approved by the Institutional Committee for Animal Care of the Lennoxville Research Centre, and animals were cared for according to guidelines of the Canadian Council on Animal Care (1993).

\section{Infusions and Sampling}

Nitrogen balance. From d 25 to 31, a 6-d total collection of feces and urine was conducted. Urine was collected in stainless steel containers via a Gooch tube (BF Goodrich Co., Kitchener, ON, Canada) attached to 
the vulva of the cow with a nylon netting covered with neoprene glued to the back of the cows. Urine was acidified by twice daily addition of $50 \mathrm{ml}$ of $10 \mathrm{~N}$ sulfuric acid to the collection vessel to prevent nitrogen loss. Aliquots of 3 and $5 \%$ of daily output of feces and urine, respectively, were sampled and frozen. At the end of the week, aliquots were thawed, pooled, subsampled, and frozen again for further analysis. During this period, feed samples were taken daily, pooled, and subsampled at the end of each collection period. Milk samples were also taken at each milking for further analysis of protein.

Leucine kinetics. On d 32, a polyvinyl catheter was inserted into a jugular vein. On d $33,\left[{ }^{13} \mathrm{C}\right]$ sodium bicarbonate was infused into a jugular vein at the rate of $0.286 \mathrm{mmol} / \mathrm{h}$ for $6 \mathrm{~h}(0900$ to $1500 \mathrm{~h})$, preceded by a priming dose of $0.4 \mathrm{mmol}$ (equivalent to 1.4 times the hourly rate; Wolfe, 1984). Breath samples were collected with a facemask, as described by Chevalier et al. (1984). Three samples were collected at approximately 15-min intervals during the hour preceding the beginning of the infusion to determine ${ }^{13} \mathrm{C}$ natural abundance in $\mathrm{CO}_{2}$ and then hourly from 2 to $6 \mathrm{~h}$ after the beginning of the infusion. The $\mathrm{CO}_{2}$ was purified from breath samples on a vacuum line, using differential freezing with a dry ice-acetone mixture and liquid nitrogen (Chevalier et al., 1984).

On d 34 or $35, \mathrm{~L}\left[1-{ }^{13} \mathrm{C}\right]$ leucine was infused, via a jugular vein, at the rate of $1.8 \mathrm{mmol} / \mathrm{h}$ for $6 \mathrm{~h}(0900$ to $1500 \mathrm{~h}$ ) preceded by a priming dose of $1.8 \mathrm{mmol}$ (equivalent to the hourly rate; Wolfe, 1984). Blood was simultaneously withdrawn from the arterial, portal, and hepatic catheters into heparinized syringes. Blood samples were collected into heparinized syringes twice during the hour preceding the infusion, to determine ${ }^{13} \mathrm{C}$ leucine natural abundance, and then hourly from 2 to $6 \mathrm{~h}$ after the onset of the infusion. In addition, blood was also collected in 1-ml heparinized syringes for $\mathrm{CO}_{2}$ analyses. Immediately after collection, two 1-ml blood aliquots were injected into evacuated Vacutainers containing $1 \mathrm{ml}$ of frozen lactic acid for measurement of $\mathrm{CO}_{2}$ enrichment ( $\mathrm{Read}$ et al., 1984). The remainder of the blood was kept on ice and centrifuged, as soon as possible, at $3000 \times g$ for $15 \mathrm{~min}$. Then, $200 \mu \mathrm{l}$ of oxohexanoate $(0.09 \mathrm{mM})$ was added to $1 \mathrm{ml}$ of plasma, as external standard for determination of 4-methyl 2oxopentanoate (MOP) concentration. All the harvested plasma was stored at $-20^{\circ} \mathrm{C}$ until analyzed. During the leucine infusion, breath samples were also collected and processed similar to the bicarbonate infusion.

Plasma flows for the portal-drained viscera (PDV) and the liver were determined by downstream dilution of sodium $p$-aminohippurate (pAH; $100 \mathrm{~g} / \mathrm{L}$ ) infused continuously $(14.4 \mathrm{~g} / \mathrm{h})$ from 0815 to $1500 \mathrm{~h}$, into one mesenteric vein catheter, following a priming dose of $2 \mathrm{~g}$.

\section{Laboratory Analyses}

Nitrogen content of composite samples of feed, feces, and urine and of individual samples of milk was determined by micro-Kjeldahl method (AOAC, 1984). The concentration of pAH was determined with an automatic analyzer (Technicon Autoanalyser II, Technicon Instruments Corporation, Tarrytown, NY), as described previously (Reynolds et al., 1992). Purified breath $\mathrm{CO}_{2}$ was analyzed for $\left[{ }^{13} \mathrm{C}\right]$ isotopic enrichment (IE) for $\mathrm{m} /$ $\mathrm{z}$ ions 44,45 , and 46 on a triple collector isotopic ratio mass spectrometer (Sira 12, VG Masslab, Manchester, UK). The blood samples taken for the determination of blood ${ }^{13} \mathrm{CO}_{2}$ IE were stored frozen on lactic acid and then, just prior to analysis, were thawed and reacted at room temperature. The IE of $\mathrm{CO}_{2}$ liberated from blood liberated from blood was analyzed using a breath carousel (BAS 50 fitted with a cryogenic gas purification system; VG Masslab) coupled to the isotopic ratio mass spectrometer. The IE of plasma free leucine and the oxo-acid, MOP, were determined after deproteinization with sulfosalicylic acid and derivatization with $\quad N$-(tert-butyldimethysilyl)- $N$-methyltrifluoroacetate-(MTBSTFA):acetronile (1:1), for $\mathrm{m} / \mathrm{z}$ ions 302 , 303 (for leucine) and 259, 260 (for MOP), by gas chromatography-mass spectrometry (Trio-1, VG Masslab), as described by Calder and Smith (1988). Isotopic enrichments for leucine, MOP, and $\mathrm{CO}_{2}$ were corrected for background abundance and expressed as atom percent excess. Concentrations of plasma leucine were determined using the isotopic dilution technique, using as the internal standard a $\left[\mathrm{U}_{-}{ }^{13} \mathrm{C}\right] \mathrm{AA}$ mixture obtained from hydrolysis of algal protein (Calder et al., 1999). The concentration of MOP was measured by comparing the area under the curve obtained during the measurement of the MOP IE and the area under the curve of the external standard (oxo-hexanoate). Blood $\mathrm{pCO}_{2}$ and $\mathrm{pH}$ were measured immediately after collection with a blood gas analyzer (model IL 1306, Instrumentation Laboratory, Lexington, MA).

\section{Calculations}

Plasma flows across the PDV and the liver were calculated from downstream dilution of $\mathrm{pAH}$ according to Katz and Bergman (1969). Net fluxes of leucine and MOP were obtained by multiplying the venous-arterial concentration differences by plasma flow.

For all given equations, the rate of infusion is $\mathrm{mmol} /$ $\mathrm{h}$ and the IE of the infusate, leucine, $\mathrm{MOP}$, or $\mathrm{CO}_{2}$ is atom percent excess. Whole body leucine irreversible loss rate (ILR ; $\mathrm{mmol} / \mathrm{h}$ ) was calculated as follows: 
Whole body leucine ILR = (rate of leucine infusion $\times$ IE of infusate)/IE $/ \mathrm{E}_{\mathrm{pp}}$

where $\mathrm{IE}_{\mathrm{pp}}$ represents the IE of the chosen precursor pool (plasma arterial free leucine or MOP). The IE of plasma free leucine or MOP was calculated as the arithmetic mean of samples taken between 2 to $6 \mathrm{~h}$ of infusion, which were at plateau condition.

Whole body fractional rate of leucine oxidation (FO) was calculated using the following equation:

$\mathrm{FO}$ of leucine $=\mathrm{IE}$ of expired $\mathrm{CO}_{2} \times \mathrm{CO}_{2}$ production $(\mathrm{mmol} / \mathrm{h}) /$

(rate of leucine infusion $\times$ IE of infusate $\times c$ )

the IE of $\mathrm{CO}_{2}$ being measured the day of leucine infusion.

The $\mathrm{CO}_{2}$ production $(\mathrm{mmol} / \mathrm{h})$ was estimated by bicarbonate infusion and calculated as:

$$
\begin{gathered}
\mathrm{CO}_{2} \text { production }=((\text { rate of bicarbonate infusion } \\
\times \mathrm{IE} \text { of infusate })- \text { rate of infusion }) \\
\times \mathrm{c} / \mathrm{IE} \text { of expired } \mathrm{CO}_{2}
\end{gathered}
$$

where the IE of $\mathrm{CO}_{2}$ was measured the day of bicarbonate infusion. The coefficient " $\mathrm{c}$ " is a correction factor for labeled $\mathrm{CO}_{2}$ sequestered in the animal and not expired. It was not estimated in the present study as it is present as a numerator and denominator in the calculation of fractional oxidation and, therefore, self-cancels.

All the following estimations of leucine and protein kinetics were calculated, when needed, with ILR estimated using the IE of plasma arterial leucine as representative of the precursor pool. Whole body leucine oxidation $(\mathrm{Ox}, \mathrm{mmol} / \mathrm{h})$ was calculated as follows:

$$
\text { leucine } \mathrm{Ox}=\mathrm{ILR} \times \mathrm{FO}
$$

The following estimations were calculated using a simple two compartment model, assuming that:

whole body leucine ILR = leucine used for protein synthesis plus leucine oxidation

$=$ leucine supply from the diet plus leucine from protein degradation.

Therefore, leucine used for whole body protein synthesis was calculated as the difference between whole body leucine ILR and leucine oxidation. Protein synthesis was then estimated assuming a constant fraction of $63 \mathrm{~g}$ of leucine/kg of synthesized tissue protein (Lobley et al., 1980) and a fraction of $98 \mathrm{~g}$ of leucine/ $\mathrm{kg}$ of milk protein (Swaisgood, 1995). Protein synthesis related to milk synthesis was estimated using only milk protein output. In addition to the estimation of leucine retained in tissues obtained from nitrogen balance $(\mathrm{N}$ ingested minus milk, feces, and urinary output), leucine retained in tissues was also calculated as:

leucine supply from the diet (net portal leucine release plus net MOP PDV release plus leucine oxidized through the PDV) minus [whole body

leucine oxidation plus leucine secreted into milk]

The addition of PDV oxidation in the first term is made to eliminate double accounting of PDV oxidation. As both the nitrogen balance and the leucine kinetic methods are not direct measurements but rather the summation of many terms and, therefore, cumulative errors, the value for leucine retained in tissues used for the calculation of protein degradation was taken as the mean of these two methods. Leucine released from protein degradation was calculated, therefore, as leucine used for protein synthesis minus leucine retained in tissues and leucine secreted in milk protein. Leucine released from protein degradation and retained as tissue protein was scaled to protein using the factor, 63 $\mathrm{g}$ of leucine $/ \mathrm{kg}$ of protein.

Leucine ILR $(\mathrm{mmol} / \mathrm{h})$ through the PDV and the liver were calculated as follows. Total splanchnic tissue (TSP) flux was the summation of the PDV and liver metabolism:

$$
\begin{aligned}
\text { PDV leucine ILR }= & \left(\mathrm{IE}_{\text {leu-P }} \times\left[\mathrm{leu}_{\mathrm{P}}\right]-\mathrm{IE}_{\text {leu-A } \mathrm{A}} \times\left[\mathrm{leu}_{\mathrm{A}}\right]\right) \\
& \times \mathrm{PF}_{\mathrm{P}} / \mathrm{IE}_{\mathrm{PP}} \\
\text { liver leucine ILR }= & \left(\left(\left(\mathrm{IE}_{\text {leu-H}} \mathrm{x}\left[\mathrm{leu}_{\mathrm{H}}\right]-\mathrm{IE}_{\text {leu-P } \mathrm{P}}\left[\mathrm{leu}_{\mathrm{P}}\right]\right)\right.\right. \\
\times & \left.\left.\left.\mathrm{PF}_{\mathrm{P}}\right)+\left(\left(\mathrm{IE}_{\text {leuH }} \mathrm{x}\left[\mathrm{leu}_{\mathrm{H}}\right]-\mathrm{IE}_{\text {leu-A }} \mathrm{x}\left[\mathrm{leu}_{\mathrm{A}}\right]\right) \times \mathrm{PF}_{\mathrm{A}}\right)\right)\right) / \mathrm{IE}_{\mathrm{pp}}
\end{aligned}
$$

where $\mathrm{IE}_{\text {leu }}$ and [leu] represent, respectively, the isotopic enrichment and concentration of plasma free leucine $(\mu M)$. Each subscript indicates the site of plasma collection (A for artery, $\mathrm{P}$ for portal vein, and $\mathrm{H}$ for hepatic vein) and $\mathrm{PF}$ represents the plasma flow $(\mathrm{L} / \mathrm{h})$ in the corresponding blood vessels. The subscript "pp" indicates that calculations were obtained using, as representative of the IE of the precursor pool, the IE of either free plasma leucine or MOP from the venous drainage of the tissues. Leucine oxidation and MOP total movement were obtained similarly, using the concentrations and IE of $\mathrm{CO}_{2}$ and MOP, respectively. Leucine used for protein synthesis across each tissue bed was calculated as the summation of leucine ILR plus the total MOP movement minus leucine oxidation. For both leucine ILR and net fluxes, a negative veno-arterial difference indicates tissue uptake, whereas a positive value denotes a release. 
Table 2. Effect of the supply of metabolizable protein (MP) on nitrogen balance in late-lactation Holstein cows. ${ }^{1}$

\begin{tabular}{|c|c|c|c|c|}
\hline \multirow[b]{2}{*}{ Nitrogen, g/d } & \multicolumn{2}{|c|}{ Treatments } & \multirow[b]{2}{*}{ SEM } & \multirow[b]{2}{*}{$P^{2}$} \\
\hline & High MP & Low MP & & \\
\hline Intake & 465 & 472 & 7 & 0.73 \\
\hline Feces & 162 & 135 & 5 & 0.02 \\
\hline Digested & 303 & 337 & 5 & 0.02 \\
\hline Urine & 173 & 187 & 8 & 0.28 \\
\hline Milk & 112 & 102 & 3 & 0.07 \\
\hline Retained in tissues & 17 & 44 & 8 & 0.05 \\
\hline
\end{tabular}

${ }^{1}$ Least squares means presented with pooled SEM, $\mathrm{n}=6$.

${ }^{2}$ Probability corresponding to the null hypothesis.

\section{Statistical Analyses}

For animal production parameters, the means of the $6 \mathrm{~d}$ of the collection period, from d 25 to 31 of each experimental period were used. For flux data, the means of each sampling day were used. Data were analyzed statistically according to the crossover design, using the GLM procedure of SAS (1985) with cows, treatments, and periods as the main effects. Treatment differences were considered significant if $P<0.10$ and as a tendency if $0.10<P<0.20$.

\section{RESULTS}

\section{$\mathrm{N}$ balance}

Whole body nitrogen balance data are presented in Table 2. Nitrogen intake did not differ $(P>0.20)$ between the two diets. Nitrogen loss in feces was smaller $(P=$ 0.02) for the Lo-MP than Hi-MP diet. This reduction resulted in a lower apparent $\mathrm{N}$ digested and apparent coefficient of $\mathrm{N}$ digestibility for the Hi-MP $\operatorname{diet}(65.0 \mathrm{vs}$. $71.3 \pm 0.83 \%, P=0.01)$. Milk $\mathrm{N}$ secretion was higher $(P$ $=0.07)$, but $\mathrm{N}$ retained in the tissues calculated with $\mathrm{N}$ balance was lower $(P=0.05)$ for the Hi-MP diet.

\section{Whole-Body Leucine Kinetics}

Whole-body leucine kinetics are reported in Table 3. Increased MP supply was associated with an increased $(P<0.01)$ whole body leucine ILR, with either arterial plasma leucine or MOP used as precursor pool, although absolute values were higher when MOP was chosen. Leucine oxidation also increased $(P=0.05)$, with the HiMP diet, although the leucine oxidation as a percentage of leucine ILR only tended $(P=0.12)$ to increase. With the Hi-MP diet, leucine used for protein synthesis increased $(P=0.01)$ as did leucine used for milk protein secretion $(P=0.07)$. Leucine retained in tissues, estimated from $\mathrm{N}$ balance increased $(P=0.05)$ with the Lo$\mathrm{MP}$ diet, averaging 2.0 and $5.7 \pm 0.85 \mathrm{mmol} / \mathrm{h}$, for the Hi-
MP and Lo-MP diets, respectively. In contrast, retention estimated from leucine supply from the diet minus leucine oxidation and leucine output in milk was not affected by treatments and averaged 4.9 and $2.9 \pm 3.19$ $\mathrm{mmol} / \mathrm{h}$, respectively. Leucine retention, averaged from the two methods, was not affected by the supply of MP while leucine arising from protein degradation increased $(P=0.02)$ with the Hi-MP diet (Table 3$)$.

\section{Splanchnic Leucine Kinetics}

Portal and splanchnic plasma flows were not affected by treatments and averaged 1193 versus $1230 \pm 37.1 \mathrm{~L} /$ $\mathrm{h}$ and 1419 versus $1426 \pm 24.9 \mathrm{~L} / \mathrm{h}$, for Hi-MP versus Lo-MP diets, respectively. Leucine net flux across the PDV and the TSP was elevated by an increased supply of MP $(P<0.01)$, while hepatic net flux was not affected by the diets (Table 4). MOP net PDV release and net hepatic removal tended $(P<0.20)$ to be higher with the Hi-MP diet.

Total leucine absorbed across the PDV (i.e., net leucine plus net MOP transfer plus that oxidized) increased ( $P$ $=0.02$ ) with the Hi-MP diet (Table 5). This was accompanied by a tendency $(P=0.11)$ for an increase in leucine oxidation across the PDV (Table 5). Conversely, there was no change in liver catabolism of leucine in response to the change in diet. Leucine used for protein synthesis in the liver tended $(P=0.17)$ to be higher in cows fed the Hi-MP diet. Furthermore, neither total leucine ILR nor the amount used to support protein synthesis across the TSP tissues were altered by diets (Table 5). In contrast to whole body measurements, fluxes across liver and digestive tract were greater based on plasma leucine as the precursor compared with MOP. Leucine enrichment (Table 6) was diluted by absorption and protein turnover across the vessels draining the TSP tissues (vessel effect: $P<0.001)$, with arterial $>$ portal $(P<0.01)$ $>$ hepatic $(P=0.05)$. There was no effect; however, of the site of sampling $(P>0.20)$ on MOP IE (Table 6). Therefore, although the enrichment of leucine was higher than that of MOP in the arterial samples, it was lower in portal and hepatic venous plasma (Table 6). The enrichments of both leucine and MOP were greater in cows fed the Lo-MP compared with the Hi-MP $\operatorname{diet}(P<0.01)$. The proportion of leucine ILR accounted by each tissue relative to whole body was calculated using only the ${ }^{13} \mathrm{C}$ movement, to eliminate any effect due to different precursor pools. The contribution of PDV, liver, and TSP leucine ILR to whole body leucine ILR averaged 33 versus $37 \pm 1.3 \%$ ( $P=0.07), 20$ versus $20 \pm 1.9 \%(P=0.83)$, and 53 versus $58 \pm 1.5 \%(P=0.08)$, for the HI-MP and lo-MP diets, respectively. 
Table 3. Effect of the supply of metabolizable protein (MP) on whole body leucine kinetics in late-lactation dairy cows. ${ }^{1}$

\begin{tabular}{|c|c|c|c|c|}
\hline \multirow[b]{2}{*}{ Leucine kinetics, $\mathrm{mmol} / \mathrm{h}$} & \multicolumn{2}{|c|}{ Treatments } & \multirow[b]{2}{*}{ SEM } & \multirow[b]{2}{*}{$P^{2}$} \\
\hline & High MP & Low MP & & \\
\hline $\mathrm{ILR}_{\mathrm{LEU}}, \mathrm{mmol} / \mathrm{h}^{3}$ & 105.3 & 84.9 & 2.5 & 0.005 \\
\hline $\mathrm{ILR}_{\mathrm{MOP}}, \mathrm{mmol} / \mathrm{h}^{4}$ & 119.3 & 103.4 & 2.1 & 0.006 \\
\hline Oxidation, $\mathrm{mmol} / \mathrm{h}^{3}$ & 22.6 & 13.7 & 2.1 & 0.05 \\
\hline Fractional oxidation, $\%$ & 21.2 & 16.0 & 1.8 & 0.12 \\
\hline Used for protein synthesis, $\mathrm{mmol} / \mathrm{h}^{3}$ & 82.7 & 71.2 & 1.6 & 0.01 \\
\hline Milk protein secretion & 22.3 & 20.3 & 0.5 & 0.07 \\
\hline Retained in tissues ${ }^{5}$ & 3.4 & 4.3 & 1.3 & 0.68 \\
\hline Coming from protein degradation 6 & 57.0 & 46.6 & 1.7 & 0.02 \\
\hline
\end{tabular}

${ }^{1}$ Least squares means presented with pooled SEM, $\mathrm{n}=6$.

${ }^{2}$ Probability corresponding to the null hypothesis.

${ }^{3}$ ILR: irreversible loss rate; LEU: calculated using plasma arterial leucine as representative of the precursor pool.

${ }^{4}$ Calculated using plasma arterial 4-methyl 2-oxopentanoate (MOP) as representative of the precursor pool.

${ }^{5}$ Estimated from the mean of $\mathrm{N}$ retention calculated with the urine and feces collection and $\mathrm{N}$ retention calculated from leucine absorption minus leucine oxidation (see Material and Methods for details).

${ }^{6}$ Calculated as leucine used for protein synthesis minus (leucine retained in tissues plus leucine secreted into milk).

\section{DISCUSSION}

\section{Calculation of Leucine Kinetics}

The dynamics of leucine metabolism was studied based on two approaches: whole body leucine ILR and tissue venoarterial differences. For accurate quantification, these both require knowledge of the enrichment of the precursor pool at the site of the metabolic event (oxidation or protein synthesis). For crossover designs in large species such as the dairy cow, routine access to deep tissue samples is impossible, and, therefore, direct measurements cannot be made on the true precursor pools, such as the charged aminoacyl-tRNA (Airhart et al., 1974). Instead, recourse is sometimes made to leucine enrichments in either the arterial inflow or venous outflow (Pell et al., 1986; Connell et al., 1997). A more popular alternative involves the enrichment of the oxo-acid (MOP, in the case of leucine); this is generated within tissues and released to the plasma and, thus, is considered to represent intracellular enrichment of the AA (Matthews et al., 1982). In arterial plasma, therefore, the enrichment of MOP (from a secondary pool) is lower than for leucine (infused into the primary pool) and, thus, calculated leucine ILR are greater (Harris et al., 1992; Bequette et al., 1996b; Lapierre et al., 1999a). However, some tissues might transaminate leucine and export the MOP, while in other tissues the MOP might be decarboxylated and thus not contribute to the plasma flux. While deamination of leucine to MOP occurs across a wide range of ruminant tissues (Goodwin et al., 1987), the majority of MOP in swine and probably in cattle in the plasma is derived from muscle (Watt et al., 1992; Quinn Baumann et al., 1994). The stability of MOP enrichment across both the PDV and the liver in sheep (Lobley et al., 1995), beef steers (Lapierre et al., 1999a), or dairy cows (current study) supports that MOP IE

Table 4. Effect of the supply of metabolizable protein (MP) on net fluxes of leucine and 4-methyl 2-oxopentanoate (MOP) across the splanchnic tissue of late-lactation dairy cows. ${ }^{1}$

\begin{tabular}{llllll}
\hline & & \multicolumn{2}{c}{ Treatments } & \\
\cline { 3 - 4 } Net flux, mmol/h & Tissue & High MP & Low MP & SEM & $P^{2}$ \\
\hline Leucine & PDV $^{3}$ & 37.4 & 29.8 & 1.0 & 0.007 \\
& Liver & 6.3 & 2.6 & 2.1 & 0.31 \\
MOP & TSP & 43.7 & 32.4 & 1.6 & 0.009 \\
& PDV & 1.5 & 1.2 & 0.1 & 0.12 \\
& Liver & -1.7 & -1.3 & 0.1 & 0.17 \\
& TSP & -0.2 & -0.2 & 0.1 & 0.71 \\
\hline
\end{tabular}

\footnotetext{
${ }^{1}$ Least squares means presented with pooled SEM, $\mathrm{n}=6$.

${ }^{2}$ Probability corresponding to the null hypothesis.

${ }^{3}$ Portal-drained viscera, TSP: total splanchnic tissues.
} 
Table 5. Effect of the supply of metabolizable protein (MP) on leucine kinetics across the splanchnic tissue in late-lactation dairy cows. ${ }^{1}$

\begin{tabular}{|c|c|c|c|c|c|}
\hline \multirow[b]{2}{*}{ Tissue $^{2}$} & \multirow[b]{2}{*}{ Kinetics, $\mathrm{mmol} / \mathrm{h}$} & \multicolumn{2}{|c|}{ Treatments } & \multirow[b]{2}{*}{ SEM } & \multirow[b]{2}{*}{$P^{3}$} \\
\hline & & High MP & Low MP & & \\
\hline \multirow[t]{5}{*}{ PDV } & Leucine $\mathrm{ILR}_{\text {leu-v }}{ }^{4}$ & -45.8 & -43.3 & 1.6 & 0.36 \\
\hline & Leucine $\mathrm{ILR}_{\mathrm{MOP}-\mathrm{v}}{ }^{5}$ & -38.8 & -38.0 & 1.8 & 0.77 \\
\hline & Leucine oxidation ${ }^{6}$ & 11.1 & 5.9 & 1.2 & 0.11 \\
\hline & Leucine used for protein synthesis ${ }^{6}$ & 33.1 & 36.0 & 1.8 & 0.33 \\
\hline & Total leucine absorbed from the small intestine ${ }^{7}$ & 49.8 & 36.9 & 2.2 & 0.02 \\
\hline \multirow[t]{4}{*}{ Liver } & Leucine ILR ${ }_{\text {leu-v }}^{4}$ & -30.3 & -25.5 & 3.6 & 0.41 \\
\hline & Leucine $\mathrm{ILR}_{\mathrm{MOP}-\mathrm{v}}{ }^{5}$ & -23.9 & -21.0 & 2.0 & 0.37 \\
\hline & Leucine oxidation $^{6}$ & 0.9 & 3.7 & 1.3 & 0.20 \\
\hline & Leucine used for protein synthesis ${ }^{6}$ & 31.4 & 23.4 & 4.6 & 0.17 \\
\hline \multirow[t]{4}{*}{ TSP } & Leucine ILR leu-v $_{-1}^{4}$ & -76.1 & -68.8 & 3.5 & 0.23 \\
\hline & Leucine $\mathrm{ILR}_{\mathrm{MOP}-\mathrm{v}}{ }^{5}$ & -62.7 & -59.0 & 1.5 & 0.17 \\
\hline & Leucine oxidation ${ }^{6}$ & 11.8 & 9.6 & 2.6 & 0.59 \\
\hline & Leucine used for protein synthesis ${ }^{6}$ & 64.5 & 59.5 & 4.0 & 0.22 \\
\hline
\end{tabular}

\footnotetext{
${ }^{1}$ Least squares means presented with pooled SEM, $\mathrm{n}=6$.

${ }^{2} \mathrm{PDV}$ : portal-drained viscera, TSP: total splanchnic tissues.

${ }^{3}$ Probability corresponding to the null hypothesis.

${ }^{4}$ ILR: irreversible loss rate, calculated using the isotopic enrichment (IE) of plasma venous leucine (leuv) as representative of the precursor pool.

${ }^{5}$ ILR: irreversible loss rate, calculated using the IE of plasma venous 4-methyl 2-oxopentanoate (MOPv) as representative of the precursor pool.

${ }^{6}$ Calculated using the IE of plasma venous leucine as representative of the precursor pool.

${ }^{7}$ Calculated as the summation of net absorption of leucine plus net absorption of MOP plus leucine oxidation across the PDV.
}

does not accurately reflect leucine transfers across the splanchnic tissues, and that plasma MOP IE is dominated by muscle metabolism.

Therefore, for splanchnic tissues, leucine enrichment in the appropriate venous drainage (portal vein for digestive tract; hepatic vein for liver) was selected as representative of the precursor pool. This approach has been vindicated for liver export proteins in sheep (Connell et al., 1997). In terms of whole body leucine ILR, the conventional approaches of using either arterial leucine or MOP enrichments to define the precursor pool are presented and, in qualitative terms, both calculations show similar responses to the dietary treatments. For comparison of the relative contributions of the various organs to whole body metabolism, values were calculated on ${ }^{13} \mathrm{C}$ transfers; this is the same as applying a common, but unspecified, precursor to all sites.

\section{Leucine Absorption and Whole Body Metabolism}

As with the other essential AA (Blouin et al., 2002), net absorption of leucine in the portal vein was greater for the Hi-MP compared with Lo-MP diet, as would be predicted with increased MP supply, even though N intakes were similar. These values are an underestimate (75 to $81 \%$ ) of the leucine absorbed across the digestive tract because of conversion to $\mathrm{MOP}(3 \%)$ and catabolism (16 to $22 \%$; as quantified by ${ }^{13} \mathrm{CO}_{2}$ produc-

Table 6. Effect of the supply of metabolizable protein (MP) on isotopic enrichment (IE) of plasma leucine and 4-methyl 2-oxopentanoate (MOP) across the splanchnic tissue measured during a $\mathrm{L}\left[1-{ }^{13} \mathrm{C}\right]$ leucine infusion in late-lactation dairy cows. ${ }^{1}$

\begin{tabular}{|c|c|c|c|c|c|}
\hline \multirow[b]{2}{*}{ IE, atom \% excess } & \multirow{2}{*}{$\begin{array}{l}\text { Source of } \\
\text { plasma }\end{array}$} & \multicolumn{2}{|c|}{ Treatments } & \multirow[b]{2}{*}{ SEM } & \multirow[b]{2}{*}{$P^{2}$} \\
\hline & & High MP & Low MP & & \\
\hline \multirow[t]{3}{*}{ Leucine } & arterial & 1.70 & 2.11 & 0.04 & 0.003 \\
\hline & portal & 1.28 & 1.53 & 0.03 & 0.006 \\
\hline & hepatic & 1.22 & 1.45 & 0.02 & 0.004 \\
\hline \multirow[t]{3}{*}{ MOP } & arterial & 1.50 & 1.73 & 0.03 & 0.01 \\
\hline & portal & 1.50 & 1.75 & 0.02 & 0.003 \\
\hline & hepatic & 1.51 & 1.74 & 0.03 & 0.008 \\
\hline
\end{tabular}

${ }^{1}$ Least squares means presented with pooled SEM, $\mathrm{n}=6$.

${ }^{2}$ Probability corresponding to the null hypothesis. 
tion) during absorption. This total absorption (net plus metabolism) was also significantly different between diets and averaged 90 and $84 \%$ of estimated digestible leucine from NRC (2001), for Hi-MP and Lo-MP diet (175 and $139 \mathrm{~g} / \mathrm{d}$ ), respectively. Metabolism of some essential AA by the digestive tract may account, in part, for the discrepancy between disappearance from the small intestine and appearance in the portal vein (Tagari and Bergman, 1978; MacRae et al., 1997b; Berthiaume et al., 2001).

The greater leucine absorption with the Hi-MP diet was reflected in both higher whole body leucine ILR and oxidation compared with the Lo-MP diet. The majority of the additional absorbed leucine was oxidized (69\%) with only $16 \%$ directed to milk protein output. The failure to account for all of the extra leucine between these fates is probably due to an underestimate of oxidation because of isotopic sequestration of labeled $\mathrm{CO}_{2}$ by various tissues (e.g., muscle, fat, skin, bone; Ram et al., 1999). The increase in whole body protein synthesis between the two diets was greater than the increase in milk protein output and, even allowing for the fact that mammary gland protein synthesis exceeds milk protein output (goats, 1.1-1.6, Bequette et al., 1996a; cows, 1.25-1.38, Bequette et al., 1996b), this suggests that the metabolic activity of other tissues has been stimulated. This agrees with observations on responses to changes in total intake in nonlactating cattle (Lobley et al., 1987; Lapierre et al., 1999a), but contradicts findings between stage of lactation in dairy goats (Bequette et al., 1994), where most of the changes in whole body synthesis could be attributed to mammary gland metabolism. Certainly, in nonlactating ruminants, peripheral tissues, muscle, and skin are sensitive to intake (Lobley et al., 1992), with elevated gain associated with increased synthesis.

Leucine used for milk protein secretion averaged $22 \%$ of whole body leucine ILR, which is lower than estimates ranging from 27 to $35 \%$ in dairy cows producing between 22 and $25 \mathrm{~kg}$ of milk/d, with DIM varying between 1 to $30 \mathrm{wk}$. (Oldham et al., 1980; Bequette et al., 1996b). These values do lie within the wider range reported for dairy goats (13 to 30\%, Champredon et al., 1990; Baracos et al., 1991; Bequette et al., 1994), with the lower proportions occurring during late lactation (in the current study, cows were over $200 \mathrm{~d}$ into lactation). In contrast, for high producing dairy cows $(45 \mathrm{~kg}$ of milk/d), the proportion of whole body leucine ILR, which was secreted into milk was greater and averaged 38\% (Lapierre et al., 1999b). These contributions, which are minimum estimates because mammary gland protein synthesis exceeds secretion (Bequette et al., 1996b), confirm the metabolic demand exerted by the udder and how this changes with milk yield and stage of lactation.

When the leucine flows are converted to whole body protein equivalents, whole body protein synthesis, total anabolic gain (milk plus tissue retention) and degradation averaged 3.74 versus $3.21,0.89$ versus 0.87 , and 2.84 versus $2.33 \mathrm{~kg} / \mathrm{d}$ for Hi-MP and Lo-MP diets, respectively. Thus, on average, $25 \%$ of the synthesized protein was converted to consumable product, even in cows producing less than $20 \mathrm{~kg}$ of milk per day. This compares with $11 \%$ conversion in growing beef cattle (Hammond et al., 1987; Eisemann et al., 1989; Lapierre et al., 1999a) and emphasizes the greater metabolic efficiencies associated with export products, such as milk, compared with tissues, such as muscle, where rates of protein synthesis and degradation are more closely balanced (Harris et al., 1992; Boisclair et al., 1993).

\section{Splanchnic Leucine Metabolism}

Half of the total body oxidation of leucine occurred within the splanchnic tissues, and this is general agreement with studies in growing sheep (Pell et al., 1986; Harris et al., 1992; Lobley et al., 1996). The BCAA are unique among the essential AA in that oxidation occurs in most of the major tissues, including fat (Goodwin et al., 1987), muscle (Pell et al., 1986; Harris et al., 1992), mammary gland (Bequette et al., 1996a, 1996b; Thivierge et al., 2002) and the PDV (Pell et al., 1986; Lobley et al., 1996). Overall, the liver appears to play a relatively minor role in leucine oxidation in ruminants (Lobley et al., 1996). In this first report from dairy cows, the hepatic contribution is only 3 to $19 \%$ of whole body oxidation, compared with 31 to $37 \%$ for the PDV (corrected for the precursor pool). In mature sheep, the rate-limiting enzyme for leucine catabolism, the branch-chain oxo-acid dehydrogenase is near maximally activated in the liver (Goodwin et al., 1987) and, therefore, the ability to respond acutely to metabolic events is limited and involves synthesis of additional enzyme protein. In contrast, in most other tissues the majority of the branch-chain oxo-acid dehydrogenase is in the inactive (phosphorylated) form (Goodwin et al., 1987; Papet et al., 1988) and acutely sensitive to metabolic regulators, such as insulin, ATP status, and leucine supply (Aftring et al., 1986; Hutson et al., 1986). In the preruminant digestive tract, leucine load activates the branch-chain oxo-acid dehydrogenase (Papet et al., 1988), via dephosphorylation of the enzyme, and the current data also suggest that elevated BCAA supply (Blouin et al., 2002) stimulates the oxidative pathway in the lactating dairy cow. Other studies have shown that leucine oxidation across the ruminant diges- 
tive tract is sensitive to changes in diet (forage level: Lobley et al., 1996), the presence of intestinal parasites (Yu et al., 2000), or lowered microbial activity following dosing with flavomycin (MacRae et al., 1999). The lack of responsiveness in leucine oxidation by the liver to diet quality (Lobley et al., 1996; current study) or leucine load (Papet et al., 1988) explains why most of absorbed BCAA are available to the peripheral tissues (Blouin et al., 2002; Lapierre et al., 2000; Wray-Cahen et al., 1997) and why hepatic fractional extraction rates decline in response to increased supply (Wray-Cahen et al., 1997; Lobley et al., 2001).

The important contribution (45 to 50\%) of the splanchnic tissues to energy utilization in the dairy cow (Johnson et al., 1990) is matched by similar inputs into whole body protein metabolism. Although some caution is necessary because of the uncertainties about the appropriate precursor pool, the current data indicate that $55 \%$ of whole body protein synthesis occurs across the liver and digestive tract, when adjustments are made to remove the effect of the precursor pool. Indeed, if data for the mammary gland are added (using an adjustment of 1.3 to convert milk protein output to mammary gland protein synthesis, Bequette et al., 1996b), then approximately $85 \%$ of whole body protein synthesis in the lactating cow is accounted by the splanchnic and mammary tissues.

The contribution of the PDV (35\%) to whole body protein synthesis is greater than observed in growing sheep (28\%, Lobley et al., 1995) or beef steers (24\%, Lapierre et al., 1999a). In all probability, this reflects the increased metabolic demand exerted via the elevated intake $(2.4 \times$ maintenance vs. $<2 \times$ maintenance in the growing ruminant studies) and might also be related with the type of feed, as growing ruminants were fed pelleted concentrates diets, while diets used in this study had an important contribution from roughages. As metabolic activities per unit weight tend to operate close to maximal for both liver and the PDV (Lobley, 1991), most of this extra demand is associated with increased organ mass. Indeed, for ruminants, there is a good relationship between metabolizable energy intake and digestive tract tissue weight $(61 \mathrm{~g} / \mathrm{kJ}$ of ME; Johnson et al., 1990), with similar values for the lactating cow (Brown et al., 1989). Hepatic mass is also related to energy intake ( $39 \mathrm{~g} / \mathrm{kJ}$ of ME; Burrin et al., 1990) and, again, the contribution of the liver to total protein synthesis is higher in the present study with dairy cows (20\%) than for either growing steers (16\%; Lapierre et al., 1999a) or sheep (11\%; Lobley et al., 1995), using similar technical approaches. Protein synthesis may be slightly overestimated as oxidation is probably underestimated, as no correction factor has been applied for $\mathrm{CO}_{2}$ sequestration within the TSP tis- sues. In contrast, the protein synthesis within other tissues, such as muscle, declines during lactation (Baracos et al., 1991), increasing the relative contributions from the splanchnic tissues and mammary gland to whole body protein metabolism.

\section{CONCLUSIONS}

An increase in MP supply increased the amount of leucine available for absorption. In combination with increased absorption for most of EAA, this led to a general stimulation of protein metabolism, with increases in whole body protein synthesis and degradation, milk protein yield, and leucine oxidation in late lactation dairy cows producing $16 \mathrm{~kg} / \mathrm{d}$. The additional leucine output as milk protein $(2 \mathrm{mmol} / \mathrm{h})$ represented only $16 \%$ of the increase supply of leucine. Catabolism of leucine was partitioned between the splanchnic and peripheral tissues and supports findings that, although supply to peripheral tissues can be enhanced by nutritional means, other factors are necessary to ensure optimum use of these extra nutrients. The interactions between these factors and nutrient supply need to be understood in order to maximize nitrogen transfer from the diet to milk protein output.

\section{ACKNOWLEDGMENTS}

The authors gratefully thank the staff of the Lennoxville dairy center for taking care of the animals, D. Bournival, G. Calder, M. Léonard and A. Roy for their dedicated technical support, as well as S. Méthot for statistical analyses. The authors also wish to acknowledge the financial support of Agriculture an Agri-Food Canada (Lennoxville research Contribution number 752), the core budget to the Rowett Research Institute from SERAD and National Sciences and Engineering Research Council of Canada.

\section{REFERENCES}

Airhart, J., A. Vidrich, and E. A. Khairallah. 1974. Compartmentation of free amino acids for protein synthesis in rat liver. Biochem. J. 140:539-548.

Aftring, R. P., K. P. Block, and M. G. Buse. 1986. Leucine and isoleucine activate skeletal muscle branched-chain ?-keto acid dehydrogenase in vivo. Am. J. Physiol. 250:E599-E604.

Association of Official Analytical Chemists. 1984. Official Methods of Analysis. 14th ed. AOAC, Arlington, VA.

Baracos, V. E., J. Brun-Bellut, and M. Marie. 1991. Tissue protein synthesis in lactating and dry goats. Br. J. Nutr. 66:451-465.

Bequette, B. J., F. R. C. Backwell, M. S. Dhanoa, A. Walker, A. G. Calder, D. Wray-Cahen, J. A. Metcalf, J. D. Sutton, D. E. Beever, G. E. Lobley, and J. C. MacRae. 1994. Kinetics of blood free and milk casein-amino acid labelling in the dairy goat at two stages of lactation. Br. J. Nutr. 72:211-220.

Bequette, B. J., F. R. C. Backwell, J. C. MacRae, G. E. Lobley, L. A. Crompton, J. A. Metcalf and J. D. Sutton. 1996a. Effect of 
intravenous amino acid infusion on leucine oxidation across the mammary gland of the lactating goat. J. Dairy Sci. 79:2217-2224.

Bequette, B. J., J. A. Metcalf, D. Wray-Cahen, F. R. C. Backwell, J. D. Sutton, M. A. Lomax, J. C. MacRae and G. E. Lobley. 1996b. Leucine and protein metabolism in the lactating dairy cow mammary gland: Responses to supplemental dietary crude protein intake. J. Dairy Res. 63:209-222.

Berthiaume, R., P. Dubreuil, M. Stevenson, B. W. McBride, and H. Lapierre. 2001. Intestinal disappearance, mesenteric and portal appearance of amino acids in dairy cows fed ruminally protected methionine. J. Dairy Sci.84: 194-203.

Blouin, J. P, J. F. Bernier, C. K. Reynolds, G. E. Lobley, P. Dubreuil, and H. Lapierre. 2002. Effect of supply of metabolizable protein on splanchnic fluxes of nutrients and hormones in lactating dairy cows. J. Dairy Sci. Accepted.

Boisclair, Y. R., A. W. Bell, F. R. Dunshea, M. Harkins, and D. E. Bauman. 1993. Evaluation of the arteriovenous difference technique to simultaneously estimate protein synthesis and degradation in the hindlimb of fed and chronically underfed steers. J. Nutr. 123:1076-1088.

Brown, D. L., S. J. Taylor, E. J. DePeters, and R. L. Baldwin. 1989. Influence of sometribove on the body composition of lactating cattle. J. Nutr. 119:633-638.

Burrin, D. G, C. L. Ferrell, R. A. Britton, and M. Bauer. 1990. Level of nutrition and visceral organ size and metabolic activity in sheep. Br. J. Nutr. 64:439-448.

Calder, A. G., and A. Smith. 1988. Stable isotope ratio analysis of leucine and ketoisocaproic acid in blood plasma by gas chromatography/mass spectrometry. Use of the tertiary butyldimethylsilyl derivatives. Rapid Commun. Mass Spectrom. 2:14-16.

Calder, A. G., K. E. Garden, S. E. Anderson, and G. E. Lobley. 1999. Quantitation of blood and plasma amino acids using isotope dilution electron impact gas chromatography/mass spectrometry with $\mathrm{U}-{ }^{13} \mathrm{C}$ amino acids as internal standards. Rapid Commun. Mass Spectr. 13:2080-2083.

Canadian Council on Animal Care. 1993. Guide to the Care and Use of Experimental Animals. Vol. 1. E. D. Offert, E. D., B. M. Cross, and A. A. McWilliam, eds. CCAC,Ottawa, Ontario.

Champredon, C., E. Debras, P. Patureau-Mirand, and M. Arnal. 1990. Methionine flux and tissue protein synthesis in lactating and dry goats. J. Nutr. 120:1006-1015.

Chevalier, R., Pelletier, G. and Gagnon, M. 1984. Sampling technique for collection of expired $\mathrm{CO}_{2}$ in studies using naturally labelled ${ }^{13} \mathrm{C}$ in calves. Can. J. Anim. Sci. 64:495-498.

Connell, A., A. G. Calder, S. E. Anderson, and G. E. Lobley, 1997. Hepatic protein synthesis in the sheep: effect of intake as monitored by use of stable-isotope-labelled glycine, leucine and phenylalanine. Br. J. Nutr. 77:255-271.

Eisemann, J. H., A. C. Hammond, and T. S. Rumsey. 1989. Tissue protein synthesis and nucleic acid concentrations in steers treated with somatotropin. Br. J. Nutr. 62: 657-671.

Goodwin, G. W., W. Gibboney, R. Paxton, R. A. Harris, and J. A. Lemons. 1987. Activities of branched-chain amino acid aminotransferase and branched-chain 2-oxo acid dehyrogease complex in tissues of maternal and fetal sheep. Biochem. J. 242:305-308.

Hammond, A. C., G. B. Huntington, P. J. Reynolds, H. F. Tyrrell, and J. H. Eisemann. 1987. Absorption, plasma flux and oxidation of L-leucine in heifers at two levels of intake. J. Anim. Sci. 64:420-425.

Harris, P. M., P. A. Skene, V. Buchan, E. Milne, A. G. Calder, S. E. Anderson, A. Connell, and G. E. Lobley. 1992. Effect of food intake on hind-limb and whole-body protein metabolism in young growing sheep: chronic studies based on arterio-venous techniques. Br. J. Nutr. 68:389-407.

Huntington, G. B., C. K. Reynolds, and B. H. Stroud. 1989. Techniques for measuring blood flow in splanchnic tissues of cattle. J. Dairy Sci. 72:1583-1595.

Hutson, S. M. 1986. Branched chain a-keto acid oxidative decarboxylation in skeletal muscle mitochindria. J. Biol. Chem. 261:4420-4425
Johnson, D. E., K. A. Johnson, and R. L. Bladwin. 1990. Changes in liver and gastrointestinal tract energy demands in response to physiological workload in ruminants. J. Nutr. 120:649-655.

Katz, M. L., and E. N. Bergman. 1969. Simultaneous measurements of hepatic and portal venous blood flow in the sheep and dog. Am. J. Physiol. 216:946-952.

Lapierre, H., J. F. Bernier, P. Dubreuil, C. K. Reynolds, C. Farmer, D. R. Ouellet, and G. E. Lobley. 1999a. The effect of intake on protein metabolism across splanchnic tissues in growing beef steers. Br. J. Nutr. 81:457-466.

Lapierre, H., G. E. Lobley, J. J. Matte, and C. L. Girard. 1999. The effect of folic acid and rumen-protected methionine on protein metabolism in dairy cows. VIIIth Int. Symp. Protein Metabolism and Nutrition. Abstr. 81.

Lapierre, H., J. F. Bernier, P. Dubreuil, C. K. Reynolds, C. Farmer, D. R. Ouellet, and G. E. Lobley. 2000. The effect of feed intake level on splanchnic metabolism in growing beef steers. J. Anim. Sci. 78:1084-1099.

LeFloc'h, N., J. N. Thibault, and B. Sève. 1997. Tissue localization of threonine oxidation in pigs. Br. J. Nutr. 77:593-603.

Lobley, G. E., V. Milne, J. M. Lovie, P. J. Reeds, and K. Pennie. 1980. Whole body and tissue protein synthesis in cattle. Br. J. Nutr. 43:491-502.

Lobley, G. E., A. Connell, and V. Buchan. 1987. Effect of food intake on protein and energy metabolism in finishing beef steers. Br. J. Nutr. 57:457-465.

Lobley, G. E. 1991. Organ and tissue metabolism: present status and future trends Pages 80-87 in Energy Metabolism of Farm Animals, 12th Kartausse Ittingen, Eds. C. Wenk and M. Boessinger. Institut fr Nutztierwissenschaften, Zurich, Switzerland.

Lobley, G. E., P. M. Harris, P. A. Skene, D. Brown, E. Milne, S. E. Anderson, P. E. Garlick, I. Nevison, and A. Connell. 1992. Responses in tissue protein synthesis to sub- and supra-maintenance intake in young growing sheep: Comparison of large-dose and continuous-infusion techniques. Br. J. Nutr. 68:373-388.

Lobley, G. E., A. Connell, E. Milne, A. M. Newman, and T. A. Ewing. 1994. Protein synthesis in splanchnic tissues of sheep fed two levels of intake. Br. J. Nutr. 71:3-12.

Lobley, G. E., A. Connell, M. A. Lomax, D. S. Brown, E. Milne, A. G. Calder, and D. A. H. Farningham. 1995. Hepatic detoxification of ammonia in the ovine liver: Possible consequences for amino acid catabolism. Br. J. Nutr. 73:667-685.

Lobley, G. E., P. J. M. Weijs, A. Connell, A. G. Calder, D. S. Brown, and E. Milne. 1996. The fate of absorbed and exogenous ammonia as influenced by forage or forage-concentrate diets in growing sheep. Br. J. Nutr. 76:231-248.

Lobley, G. E., D. M. Bremner, and D. S. Brown. 2001. Response in hepatic removal of amino acids by the sheep to short-term infusions of varied amounts of an amino acid mixture into the mesenteric vein. Br. J. Nutr. 85:689-698.

MacRae, J. C., L. A. Bruce, D. S. Brown, and A. G. Calder. 1997a. Amino acid use by the gastrointestinal tract of sheep given lucerne forage. Am. J. Physiol. 273:G1200-G1207.

MacRae, J. C., L. A. Bruce, D. S. Brown, D. A. H. Farningham, and M. F. Franklin. 1997b. Absorption of amino acids from the intestine and their net flux across the mesenteric and portal drained viscera of lambs. J. Anim. Sci. 75:3307-3314.

MacRae, J. C., L. A. Bruce, and F. Yu. 1999. The effect of Flavomycin on gastrointestinal leucine metabolism and liveweight gain in lambs. S. Afr. J. Anim. Sci. 29(ISRP):243-244.

Matthews, D. E., H. P. Schwarz, R. D. Yang, K. J. Motil, V. R. Young, and D. M. Bier. 1982. Relationship of plasma leucine and alphaketoisocaproate during a L- $\left[1-{ }^{13} \mathrm{C}\right]$ leucine infusion in man: a method for measuring human intracellular leucine tracer enrichment. Metabolism. 11:1105-1112

National Research Council. 2001. Nutrient Requirements of Dairy Cattle. 7th rev. ed. Natl. Acad. Sci., Washington, DC.

Oldham, J. D., G. E., Lobley, B. A., Konig, D. S., Parker, and R. W., Smith. 1980. Amino acid metabolism in lactating dairy cows early in lactation. Pages 458-463 in Protein Metabolism in Nutrition. H. J. Oslage and K. Rohr, eds. EAAP No. 27, ICBL, Braunschweig, Germany. 
Papet, I., N. Lezebot, F. Barre, M. Arnal, and A. E. Harper. 1988. Influence of dietary leucine on the activities of branched-chain amino acid aminotransferase (EC 2.6.1.42) and branched-chain keto acid dehyrogenase ( $E C$ 1.2.4.4) complex in tissues of preruminant lambs. Br. J. Nutr. 59:475-483.

Pell, J. M., E. M. Caldarone, and E. N. Bergman. 1986. Leucine and ?-ketoisocaproate metabolism and interconversions in fed and fasted sheep. Metabolism 35:1005-1016.

Quinn Baumann, P., W. S. Stirewalt, B. D. O'Rourke, D. Howard, and S. Nair. 1994. Precursor pools of protein synthesis: A stable isotope study in swine model. Am. J. Physiol. 267: E203-209.

Ram, L., R. Nieto, and G. E. Lobley. 1999. Tissue sequestration of C-labelled bicarbonate [HCO3-] in fed and fasted young sheep. Comp. Biochem. Physiol. Part A:122: 323-330.

Read, W. W., M. J. Read, R. C. Griggs, and D. Halliday. 1984. Preparation of $\mathrm{CO}_{2}$ from blood and protein-bound amino acid carboxyl groups for quantification of ${ }^{13} \mathrm{C}$-isotope enrichments. Biomed. Mass Spectr. 15:467-472.

Reynolds, C. K., H. Lapierre, H. F. Tyrrell, T. H. Elsasser, R. C. Staples, P. Gaudreau, and P. Brazeau. 1992. Effects of growth hormone-releasing factor and feed intake on energy metabolism in growing beef steers: Net nutrient metabolism by portal-drained viscera and liver. J. Anim. Sci. 70:752-763.

Schaefer, A. L., S. R. Davis, and G. A. Hughson. 1986. Estimation of tissue protein synthesis in sheep during sustained elevation of plasma leucine concentration by intravenous infusion. Br. J. Nutr. $56: 281-288$

SAS User's Guide: Statistics. Version 5 Edition. 1985. SAS Inst., Inc., Cary, NC.
Swaisgood, H. E. Protein and amino acid composition of bovine milk. 1995. Pages 464-472 in Handbook of Milk Composition. R. G. Jensen, ed. Academic Press, London, UK.

Tagari, H., and E. N. Bergman. 1978. Intestinal disappearance and portal appearance of amino acids in sheep. J. Nutr. 108:790-803.

Thivierge, M. C., D. Petitclerc, J. F. Bernier, Y. Couture, and H. Lapierre. 2002. Variations of mammary metabolism as the udder gradually fills with milk during a 12 -h period following milking: Leucine kinetics. J. Dairy Sci. (In press).

van Goudoever, J. B., B. Stoff, J. F. Henry, D. G. Burrin, and P. J. Reeds. 2000. Adaptive regulation of intestinal lysine metabolism. Proc. Natl. Acad. Sci. USA 97:11620-11625.

Watt, P. W., M. E. Corbett, and M. J. Rennie. 1992. Stimulation of protein synthesis in pig skeletal muscle by infusion of amino acids during constant insulin availability. Am. J. Physiol. 263 (Endocrinol. Metab. 26):E453-E460.

Wolfe, R. R. 1984. Tracers in metabolic research. Radioisotope and stable isotope/mass spectrometry methods. Alan R. Liss, Inc., New York.

Wray-Cahen, D., J. A. Metcalf, F. R. C. Backwell, B. J. Bequette, D. S. Brown, J. D. Sutton, and G. E. Lobley 1997. Hepatic response to increased exogenous supply of plasma amino acids by infusion into the mesenteric vein of Holstein-Friesian cows in late gestation. Br. J. Nutr. 78:913-930.

Yu, F., L. A. Bruce, A. G. Calder, E. Milne, R. L. Coop, F. Jackson, G. W. Horgan, and J. C. MacRae. 2000. Subclinical infection with the nematode Trichostrongylus colubriformis increases gastrointestinal tract leucine metabolism and reduces availability of leucine for other tissues. J. Anim. Sci. 78:380-39. 